\title{
CS-38 -Implementación de estrategias de mejora en la atención a la salud pública en la población indígena
}

\author{
Implementation of strategies to improve public health care for \\ indigenous population \\ Karla Violeta Cuj Medina*, Luigi César Jiménez Aké, Juan Francisco Chávez Dehesa \\ Universidad Tecnológica del Usumacinta, Tabasco, México
}

*Autora a quien se dirige la correspondencia:kcujmedina@hotmail.com

\section{Resumen}

- 1 documento plantea los tipos de dificultades que presentan los indígenas en la zona colindante a la cuidad de Palen- que, Estado de Chiapas, en la oferta de las servicios de salud, una cobertura limitada, que obedece a restricciones en la amplitud, profundidad y frecuencia de estos, y la cobertura nula, debido a carencia de oferta de sistemas de salud, a problemas de acceso geográfico difícil a las unidades de atención médica, a rechazo de la atención médica por parte de las comunidades indígenas, encontrándose entre otras causas la barrera del lenguaje. Es por ello que esta trabajo tiene como objetivo concientizar a los prestadores de servicio de salud la importancia de generar información en lengua nativas esta información se lleva a cabo por medio de pláticas y carteles sobre la interculturalidad de la población indígena y su lengua originaria. Estos indicadores de rezago en los grupos indígenas generan una desigualdad en los accesos a los servicios que brinda el gobierno a la población, entre ellos los de salud pública, ya que el principal problema analizado en la ciudad de Palenque, Chiapas es una atención medica limitada por la relación médico- paciente.Por lo que se refiere a unidades médicas de segundo nivel de atención, debe destacarse, que en los municipios con mayor porcentaje de población indígena hay una limitada disponibilidad de este recurso de salud, en comparación con aquellos cuyo porcentaje es menor de población indígena.

Palabras claves: Estrategias, indígenas, salud, lenguaje, atención

\section{Abstract}

$\mathrm{D}$ ocument outlines the types of difficulties presented by indigenous people in the area adjacent to the city of Palenque, Chiapas, in the supply of health services, Limited coverage, which is due to restrictions on the breadth, depth and frequency of these, and no coverage due to lack of supply of health systems, problems of difficult geographic access to health care units, a rejection of health care by indigenous communities, being among other reasons the language barrier. That is why this paper aims to raise awareness among health service providers the importance of generating information in native language this information is carried out through talks and posters about multiculturalism of the indigenous population and their native language. These indicators lag indigenous groups generate an inequality in access to services provided by the government to the population, including public health, since the main problem discussed in the city of Palenque, Chiapas is a limited medical care by doctor-patient relationship. As regards medical units of second level attention, it should be noted that in municipalities with the highest percentage of indigenous population there is limited availability of this resource health, compared to those whose percentage is lower indigenous population.

Key words: Implementation, indigenous, health, language, improve 